\title{
Effects of Preferential Delta and Kappa Opioid Receptor Agonists on the Intake of Hypotonic Saline
}

\author{
BLAKE A. GOSNELL, MARK J. MAJCHRZAK AND DEAN D. KRAHN \\ University of Michigan, Department of Psychiatry, University Hospital, 8D8806, Box 0116 \\ Ann Arbor, MI 48109-0116
}

Received 16 November 1989

\begin{abstract}
GOSNELL, B. A., M. J. MAJCHRZAK AND D. D. KRAHN. Effects of preferential delta and kappa opioid receptor agonists on the intake of hypotonic saline. PHYSIOL BEHAV 47(3) 601-603, 1990. - A previous study has implicated central mu opioid receptors in the preference for salt solutions. Because mu, kappa and delta receptors are all thought to play a role in food intake and/or the mediation of palatability, we performed a series of experiments to determine whether preferential agonists at kappa and delta receptors might also stimulate the intake of salt solutions. When injected centrally into nondeprived rats, two selective agonists at delta receptors caused increases in the intake of $0.6 \%$ saline; the intake of concurrently available water was either unchanged or slightly increased. The selective kappa agonist U-50,488H had no effect on water or saline intake, whereas the preferential kappa agonist DAFPHEDYN caused a delayed increase in saline intake. These results indicate a role for central delta receptors in the preference for salt solutions, and are consistent with the suggestion that opioids play a role in the mediation of palatability.
\end{abstract}

Opioids Palatability Taste preference Reward Drinking Saline intake

SEVERAL reports have suggested that endogenous opioids play a role in mediating palatibility [see $(5,12)$ for reviews]. Generally, opioid antagonists have been found to decrease the preference for (or intake of) palatable fluids $(3,5,8)$, while opioid agonists increase preferences $(2,8)$. Although most studies have dealt with the consumption or preferences for sweet-tasting fluids, there are indications that these opioid effects can also be obtained with nonsweet palatable fluids. Hypo- and isotonic salt solutions are preferred over water even in salt-replete rats (10), which suggests that these solutions are palatable to rats. Naloxone caused a selective reduction in the intake of hypotonic saline solutions (4), and reduced $0.9 \%$ saline intake at lower doses than those required to reduce water intake (11). In water-deprived rats, systemic injections of morphine increased rats' preference for isotonic saline (1),

There are at least three types of opioid receptors, the best characterized being the mu, kappa and delta (6). Recently, we found that a selective mu agonist stimulates the intake of hypotonic $(0.6 \%)$ saline in nondeprived rats (9). Because mu, kappa and delta receptors are all thought to play a role in food intake and/or the mediation of palatability $(5,7-9)$, we performed a series of experiments to determine whether preferential agonists at kappa and delta receptors might also stimulate the intake of salt solutions. The delta agonists used were [D-Thr $\left.{ }^{2}, \mathrm{Leu}^{5}\right]$ enkephalin$\mathrm{Thr}^{6}$ (DTLET) and [D-Pen ${ }^{2}$, D-Pen ${ }^{5}$ enkephalin (DPDPE); the kappa agonists were $\mathrm{U}-50,488 \mathrm{H}$ and a recently reported dynorphin analog, $\left[\mathrm{D}-\mathrm{Ala}^{2},\left(\mathrm{~F}_{5}\right) \mathrm{Phe}^{4}\right]$-dynorphin ${ }_{1-13}-\mathrm{NH}_{2}$ (DAFPHEDYN) (13).

\section{METHOD}

Male Sprague-Dawley rats (Charles River Laboratories, Inc., Wilmington, MA) were used in all experiments. At the time of surgery, body weights ranged from 239-345 g. They were individually housed in stainless steel cages, and food and water were available ad lib, except as described below. Lights were on for 12 hours daily, and all experiments were carried out in the light period. A 20-gauge cannula was implanted into the right lateral ventricle of each rat with techniques similar to those previously reported $(8,9)$. Cannula placement was verified by the observation of a drinking response to an ICV injection of angiotensin U (AII, $100 \mathrm{ng}$ ). All rats were tested at least once with AII, and all data from animals drinking less than $5 \mathrm{ml}$ in $30 \mathrm{~min}$ on all tests were excluded. Adaptation to testing procedures began no sooner than 3 days after surgery.

After an overnight period of water deprivation, rats were moved to individual test cages for adaptation to the testing procedure. One hour later, a $0.6 \%$ sodium chloride (saline) solution was presented to each rat in a $25-\mathrm{ml}$ graduated buret fitted with a stainless steel sipper tube. After two hr of access to this solution, rats were returned to their home cages. After this first 


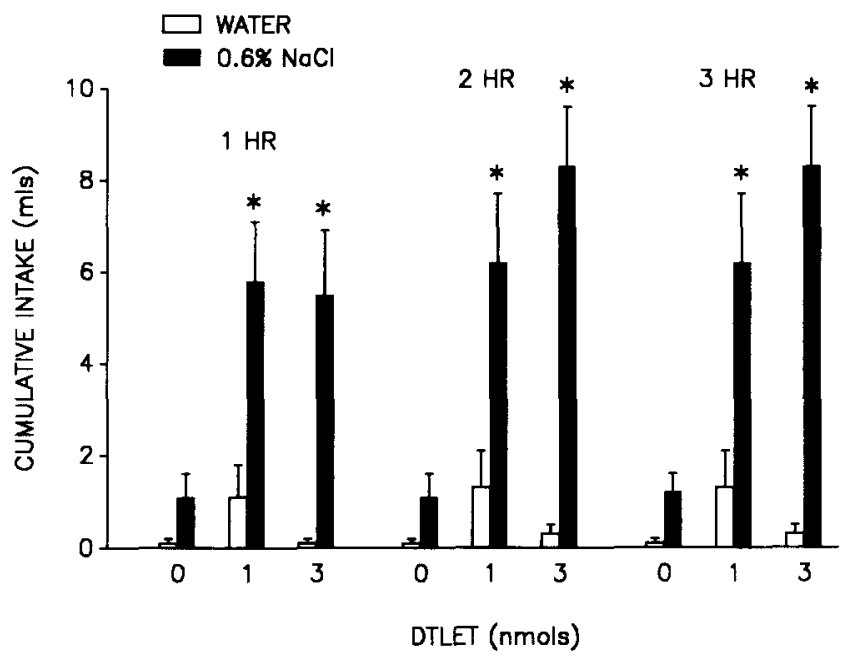

FIG. 1. Cumulative intake of water and $0.6 \%$ saline following ICV injections of the delta agonist DTLET (mean \pm S.E.M.). All rats were tested in the nondeprived condition, and each rat was tested with all doses $(n=9)$. Asterisks indicate significant increases above the corresponding 0 nmol (saline) condition ( $p<0.05$, one-tailed Dunnett's test).

adaptation session, water was available ad lib in the home cages for the remainder of the experiment. Food was available in the home cages, but not the test cages. For the next 10-11 days, this adaptation procedure was repeated in a similar manner, except that two burets were attached to the test cages each day: one contained $0.6 \%$ saline and the other contained water. The positions of the two burets were reversed daily.

The effects of DTLET were tested with a repeated measures design. On the first test day, rats were given ICV injections of 0 ( $0.9 \%$ saline), 1 or $3 \mathrm{nmol}$ of DTLET in a $5 \mu$ l volume. Injections were given at the time of placement into the test cages, and burets were placed on the cages $30 \mathrm{~min}$ after injection. This delay between injections and fluid access was imposed because, in previous studies, we have found that DTLET in this dose range produces a cataleptic state which dissipates within $30 \mathrm{~min}$. On test days, rats were given 3 hours access to saline and water, after which they were returned to their home cages. Saline and water intakes were measured every hour. The test procedure was repeated two additional times, such that every rat was tested with placebo and with both doses of DTLET. Test days were 2-4 days apart; on the intervening days, rats were given $2 \mathrm{hr}$ access to water and saline without injections. Injection orders for testing the three doses were varied across rats, such that every dose was tested in at least one rat on each of the three days. For each fluid, Dunnett's test (one-tailed) was used at each measurement to compare intake in each DTLET condition to the control condition.

To determine whether DTLET would stimulate water intake when saline was not available, rats with previous experience with central DTLET injections and with drinking either $0.6 \%$ or $1.7 \%$ saline were tested in a single trial similar to those described above. Thirty min after ICV injections of saline $(n=4)$ or DTLET $(3$ $n m o l, n=4$ ), a single buret containing water was attached to each cage, and intake was measured hourly for $3 \mathrm{hr}$.

In three separate groups of rats, the effects of DPDPE [0 (saline), 15.5 and $46.5 \mathrm{nmol}$ ], DAFPHEDYN [0 (water), 1 and 3 nmol], and $U-50,488 \mathrm{H}$ [0 (saline), 10 and $30 \mathrm{nmol}]$ were tested with procedures similar to those described above, with only a few minor exceptions. DAFPHEDYN, DPDPE and U-50,488H rats were given 8,10 and 11 days, respectively, of adaptation to the test cages and saline solutions. During adaptation, water and saline were presented $60 \mathrm{~min}$ (DAFPHEDYN rats), or $15-30 \mathrm{~min}$ (DPDPE and U-50,488H rats) after placement into the test cages. On injection days, DPDPE and $\mathrm{U}-50,488 \mathrm{H}$ rats were transferred to the test cages at the time of injection; DAFPHEDYN rats were transferred $45 \mathrm{~min}$ before injections. In test of all three agonists, burets were placed on the cages $15 \mathrm{~min}$ after injections. U$50,488 \mathrm{H}$ trials were 2 rather than $3 \mathrm{hr}$ in duration. DAFPHEDYN was dissolved in HPLC grade water; all other agonists were dissolved in saline. DAFPHEDYN was synthesized by Dr. David Coy (Tulane University) and was provided by Dr. Hylan Moises (University of Michigan). U-50,488H was purchased from the Upjohn Co. (Kalamazoo, MI); all other peptides were purchased from Sigma Chemical Co. (St. Louis, MO).

We are not aware of any previous studies on the effects of DAFPHEDYN on ingestive behaviors. Therefore, in addition to testing its effects on saline intake, we measured the effects of similar doses on food intake. A separate group of rats were cannulated as described above. In two trials (at least 2 days apart), food intake was measured $0.5,1$ and $2 \mathrm{hr}$ after ICV injections of DAFPHEDYN $(0.5 \mathrm{nmol})$ and saline. In two additional pairs of

TABLE 1

EFFECTS OF THREE OPIOID AGONISTS ON THE INTAKE OF WATER AND $0.6 \% \mathrm{NaCl}$

\begin{tabular}{lccccr}
\hline & \multicolumn{2}{c}{$1 \mathrm{Hr}$} & \multicolumn{2}{c}{$2 \mathrm{Hr}$} \\
Agonist & $\begin{array}{c}\text { Dose } \\
(\mathrm{nmol})\end{array}$ & Water & $0.6 \% \mathrm{NaCl}$ & Water & $0.6 \% \mathrm{NaCl}$ \\
\hline & & & & & \\
DPDPE & 0 & $0.4 \pm 0.1$ & $2.2 \pm 0.5$ & $0.5 \pm 0.1$ & $2.4 \pm 0.6$ \\
$(\mathrm{n}=21)$ & 15.5 & $1.1 \pm 0.4$ & $* 4.7 \pm 0.7$ & $* 1.2 \pm 0.4$ & $* 4.8 \pm 0.7$ \\
& 46.5 & $0.9 \pm 0.2$ & $* 5.0 \pm 0.9$ & $1.0 \pm 0.2$ & $* 5.3 \pm 1.0$ \\
$\begin{array}{c}\text { DAFPHEDYN } \\
(\mathrm{n}=9)\end{array}$ & 0 & $0.6 \pm 0.3$ & $2.2 \pm 1.0$ & $0.6 \pm 0.3$ & $2.2 \pm 1.0$ \\
& 1 & $0.1 \pm 0.04$ & $2.5 \pm 0.6$ & $0.1 \pm 0.04$ & $3.3 \pm 0.6$ \\
U-50,488H & 3 & $0.1 \pm 0.1$ & $2.8 \pm 1.2$ & $0.3 \pm 0.1$ & $* 6.1 \pm 1.6$ \\
$(\mathrm{n}=8)$ & 0 & $0.08 \pm 0.05$ & $2.3 \pm 0.6$ & $0.1 \pm 0.04$ & $2.8 \pm 0.8$ \\
& 10 & $0.08 \pm 0.04$ & $1.7 \pm 1.1$ & $0.1 \pm 0.04$ & $2.2 \pm 1.2$ \\
& 30 & $0.03 \pm 0.02$ & $0.8 \pm 0.5$ & $0.2 \pm 0.15$ & $1.3 \pm 1.0$ \\
\hline
\end{tabular}

*Significantly different from control $(0 \mathrm{nmol})$; Dunnett's test (one-tailed, $p<0.05$ ). 
trials with the same rats, saline vs. $1 \mathrm{nmol}$ and saline vs. $3 \mathrm{nmol}$ were tested. Dunnett's test was used to compare the mean intake after each dose of DAFPHEDYN to the mean intake of the pooled saline trials.

\section{RESULTS}

DTLET ( 1 and $3 \mathrm{nmol}$ ) caused selective increases in $0.6 \%$ saline intake measured at 1,2 and 3 hours (Fig. 1). Water intake was minimal and not affected by DTLET. When only water was available, DTLET caused a small but significant increase in 2 - and 3-hr cumulative water intake. DTLET-injected rats drank $1.1 \pm 0.5$, $2.1 \pm 0.6$ and $2.1 \pm 0.6 \mathrm{ml}$ at 1,2 and $3 \mathrm{hr}$, respectively; saline-injected rats consumed only $0.3 \pm 0.3 \mathrm{ml}$ in 3 hours. DAFPHEDYN ( $3 \mathrm{nmol}$ ) also caused selective increases in cumulative $0.6 \%$ saline intake measured at 2 and 3 hours (Table 1). Three-hour results were similar to 2-hour results and are, therefore, not shown. Water intake was minimal (less than $1.0 \mathrm{ml}$ ) and was not affected by DAFPHEDYN. DPDPE (15.5 and $46.5 \mathrm{nmol}$ ) caused significant increases in saline intake at each measurement; water intake was slightly increased by $1 \mathrm{nmol}$ dose. U-50,488H did not significantly affect water or saline intake.

In the feeding trials with DAFPHEDYN, food intake was significantly increased by the $1 \mathrm{nmol}$ dose at $0.5 \mathrm{hr}$, by the $3 \mathrm{nmol}$ dose at $1 \mathrm{hr}$, and by the 1 and $3 \mathrm{nmol}$ doses at two $\mathrm{hr}(p<0.05)$. At $2 \mathrm{hr}$, mean intakes were $0.1 \pm 0.1,0.9 \pm 0.5,1.9 \pm 0.5$ and $2.5 \pm 1.0 \mathrm{~g}$ for the $0,0.5,1$ and $3 \mathrm{nmol}$ doses respectively $(\mathrm{n}=7)$.

\section{DISCUSSION}

We recently reported that central administration of a selective $\mathrm{mu}$ agonist stimulates saline intake in nondeprived rats (9). Because agonists at delta and kappa receptors are also thought to play a role in the mediation of taste preferences or the rewarding value of food, we measured the effects of two kappa and two delta agonists on the intake of a palatable salt solution. The delta agonists DTLET and DPDPE clearly caused preferential increases in the intake of $0.6 \%$ saline. That DTLET caused only a small increase in intake when only water was available suggests that the observed effects are not due simply to a generalized dipsogenesis. Furthermore, our recent report (8) that a mu and a delta agonist also stimulated saccharin intake indicates that the present results are not limited to the intake of saline solutions. These results, then, are consistent with the hypothesis that opioids are involved in the mediation of palatability $(5,12)$.

A clear role for kappa receptors in the control of saline intake was not demonstrated. The ineffectiveness of $\mathrm{U}-50,488 \mathrm{H}$ may possibly be attributed to subthreshold doses. The doses tested (10 and $30 \mathrm{nmol}$ ) were selected because we recently found that higher doses ( 30 and $100 \mathrm{nmol}$ ) tended to decrease the intake of a palatable saccharin solution (8). The preferential kappa agonist DAFPHEDYN ( $3 \mathrm{nmol}$ ) caused a delayed increase in saline intake; doses of 1 and $3 \mathrm{nmol}$ were also effective in stimulating food intake. That the effect on saline intake was not apparent until the second hourly measurement suggests the possibility that the increase was secondary to its diuretic effect (13). It is also possible that the effect of DAFPHEDYN is due to its action at mu receptors, as its affinity for mu receptors is only 2-fold less than that for kappa receptors (13).

These results extend our previous research and indicate a role for central delta as well as mu receptors in the intake of or preference for palatable solutions. Additional testing with wider dose ranges of selective agonists will be necessary to determine whether kappa receptors may also be involved.

\section{ACKNOWLEDGEMENT}

This research was supported by NIDA grant DA05471.

\section{REFERENCES}

1. Bertino, M.; Abelson, M. L.; Marglin, S. H.; Neuman, R.; Burkhardt, C. A.; Reid, L. D. A small dose of morphine increases intake of and preference for isotonic saline among rats. Pharmacol. Biochem. Behav. 29:617-623; 1988.

2. Calcagnetti, D. J.; Reid, L. D. Morphine and acceptability of putative reinforcers. Pharmacol. Biochem. Behav. 18:567-569; 1983.

3. Cooper, S. J. Effects of opiate agonists and antagonists on fluid intake and saccharin choice in the rat. Neuropharmacology 22:323-328; 1983.

4. Cooper, S. J.; Gilbert, D. B. Naloxone suppresses fluid consumption in tests of choice between sodium chloride solutions and water in male and female water-deprived rats. Psychopharmacology 84:362-367; 1984.

5. Cooper, S. J.; Jackson, A.; Kirkham, T. C.; Turkish, S. Endorphins, opiates and food intake. In: Rodgers, R. J.; Cooper, S. J., eds. Endorphins, opiates and behavioral processes. New York: John Wiley and Sons; 1988:143-186.

6. Goldstein, A.; James, I. F. Multiple opioid receptors-criteria for identification and classification. Trends Pharmacol. Sci. 5:503-505; 1984.
7. Gosnell, B. A. Central structures involved in opioid-induced feeling. Fed. Proc. 46:163-167; 1987

8. Gosnell, B. A.; Majchrzak, M. J. Centrally administered opioid peptides stimulate saccharin intake in nondeprived rats. Pharmacol. Biochem. Behav. 33:805-810; 1989.

9. Gosnell, B. A.; Majchrzak, M. J. Effects of a selective mu opioid receptor agonist and naloxone on the intake of sodium chloride solutions. Psychopharmacology (Berlin) 100:66-71; 1990.

10. Khavari, K. A. Some parameters of sucrose and saline ingestion. Physiol. Behav. 5:663-666; 1970.

11. Levine, A. S.; Murray, S. S.; Kneip, J.; Grace, M.; Morley, J. E. Flavor enhances the antidipsogenic effect of naloxone. Physiol. Behav. 28:23-25; 1982.

12. Reid, L. D. Endogenous opioid peptides and regulation of drinking and feeding. Am. J. Clin. Nutr. 42:1099-1132; 1985.

13. Walker, J. M.; Coy, D. H.; Young, E. A.; Baldrighi, G.; Siegel, S. F.; Bowen, W. D.; Akil, H. [D-Ala ${ }^{2},\left(\mathrm{~F}_{5}\right)$ Phe $\left.^{4}\right]$-Dynorphin ${ }_{1-13}-\mathrm{NH}_{2}$ (DAFPHEDYN): A potent analog of dynorphin 1-13. Peptides $8: 811-817 ; 1987$. 